produce such changes in diet as indicate that the low nutritional-level of the major sections is more a function of economic conditions than of racial tradition or disposition. The exported food of the world as a whole shows a markedly erratic distribution : for example, the English-speaking countries and parts of Western Europe absorbed in times of peace almost the whole of the fruit and sugar which eame on to the world markets. What is to be the policy of these favoured countries in a world governed by the principles of the Atlantic Charter?

\section{Social and Industrial Environment and Disease}

Hippocrates, in a famous passage, said that in forming a judgment on the outcome of illness not only the individual nature of the patient but also his environment, physiological and psychological, must be considered. This formed the text for a Chadwick Public Lecture delivered on February 23 by Prof. M. Greenwood, who suggested practicable lines of study for the medical student. In the first place, some knowledge of the housing position of England and Wales, as it was and is, is necessary. It is easy to forget that, in some parts of the country, the housing position is still very bad, and that rehousing schemes have not always been successes. In the next place, although scientific study of the influence of occupation on health is hundreds of years old, the earlier work was mainly devoted to specific occupational hazards, the noxious dusts and fumes. More general work on environmental effects is a generation old, but has been greatly neglected in education. Evidence of this is that at the beginning of the present war, and indeed still, the work of the Health of Munition Workers Committee and its successor, the Industrial Health Research Board, has been very largely ignored. One reason for this is that medical students and practitioners, overburdened by the demands of an ever-lengthening curriculum, have neither the training nor the leisure to study papers often of a technical character written by research workers who are usually not members of the medical profession. To prepare the way for improvement it is desirable that all medical students should receive an elementary training in statistical method. Both epidemiology and general social hygiene, because they are concerned with groups rather than individuals, must employ methods of averaging, that is, statistical methods. It is also neeessary that more serious attention should be paid to the study of psychology.

\section{Institute of Chemistry}

At the sixty-fifth annual general meeting of the Institute of Chemistry, Dr. J. J. Fox, the retiring president, said that the roll has increased to 8,250 fellows and associates and more than 950 students. The Institute has joined with the Institute of Physics and representatives of other sciences in forming a Joint Council of Professional Scientists to watch their common interests and give expression to the opinions of professional scientists as occasions arise. The Joint Council is in touch with the appropriate authorities in considering the probable position of scientific workers after the War. There has been much discussion among chemists on the future policy of the Institute and on the possibility of closer cooperation between the various organizations devoted to the science and profession. The main objects of the Institute are to promote the education and train- ing of professional chemists, to hold examinations, to grant certificates of competency, to organize and register the competent, and to render every possible assistance to the Government, industry and commerce by encouraging the employment of chemists. Endeavours to promote co-operation at the present time by means of joint membership have not been so well supported as had been hoped by the Chemical Council, a body constituted under a deed of agreement between the Institute, the Chemical Society and the Society of Chemical Industry, which has now been asked to consider the possibility of coordinating the services performed by the various bodies for chemists and chemistry. Prof. Alexander Findlay, of the University of Aberdeen, has been elected president of the Institute.

\section{University of London}

THE title of professor emeritus of botany in the University of London has been conferred on Prof. R. Ruggles Gates on his retirement from the chair of botany at King's College.

The degree of D.Sc. has been conferred on : $\mathbf{M r}$. A. G. Gaydon (Imperial College of Science and Technology); Mr. S. H. Jenkins (Rothamsted Experimental Station); Mr. J. T. Martin (Rothamsted Experimental Station); Mr. C. B. Taylor (Rothamsted Experimental Station); Mr. A. F. B. Zeuner (Institute of Archæology).

The William Julius Mickle fellowship has been awarded to Prof. E. C. Dodds, Courtauld professor. of biochemistry in the Middlesex Hospital Medical School.

\section{Foreign Books and Trănslations}

Mr. JoHN HAMPden, director of the Books and Periodicals Department of the British Couneil, is appealing for books of every type in Arabic, Chinese, Czech, Danish, Dutch, modern Greek, Norwegian, Polish, Serbo-Croat and Urdu for presentation to institutions and individuals in the British Empire, foreign countries and among men of the Allied fighting services and merchant seamen in Great Britain. Standard works, including advanced text-books, in French are also required. Translations into any of these languages of standard works in English would be particularly welcome. Offers should be addressed to the British Council (Foreign Books), The College, South Leigh, near Witney, Oxford.

\section{Social Welfare in the Colonies}

A Colonial Social Welfare Advisory Committee has been appointed by the Secretary of State for the Colonies to advise him on problems affecting the social welfare of urban and rural communities in the Colonies, on the training of social welfare workers, and on allied matters. The Committee consists of : The Duke of Devonshire, Parliamentary UnderSecretary of State (chairman); Sir Charles Jeffries, Assistant Under-Secretary of State (vice-chairman); Prof. A. M. Carr-Saunders, director, London School of Economics and Political Science; Miss Margery Fry, well-known authority on juvenile delinquency; Miss L. Harford, chief woman officer, National Council of Social Service; Mr. J. Longland, director of education, Dorset; Mr. E. H. Lucette, secretary, Dr. Barnardo's Homes ; Miss Margaret Nixon, chief superintendent of welfare at the Admiralty ; Mr. A. 